\title{
DOI 10.26886/2414-634X.1(20)2018.3
}

UDC 69.059.7:65.011.1:72.03

"CSTC T-PPR": ARCHITECTURAL AND HISTORICAL DEVELOPMENT OF ODESSA IN XIX ... THE BEGINNING OF THE XX-th CENTURIES

\section{Posternak, PhD in Technical Sciences, Associate Professor}

The Odessa state academy of building and architecture, Ukraine, Odessa

\section{S. Posternak, PhD in Technical Sciences, Associate Professor}

Private company "Composite", Ukraine, Odessa

It is offered to create in the city of Odessa "the Corporate scientific and technical complex town-planning power reconstruction "CSTC T-PPR", as innovative organizational structure which uses in practice the saved up scientific and technical potential for reconstruction of buildings of historical building of Odessa under standards power efficiency. It is executed researches of historically-style development which is characterized by the big scope of civil work and presence of various styles. Superstructures were carried out in a city practically during all history its development. The mansard floor is an effective variant a superstructure buildings of background building.

Key words: a corporate scientific and technical complex, town-planning power reconstruction, formation of Odessa, architectural styles, buildings of historical building.

кандидат технічних наук, доцент, Постернак І. М., кандидат технічних наук, доцент, Постернак С. О. КНТК МЕРек: архітектурно-історичний розвиток Одеси в XIX ... на початку XX століття/ Одеська державна академія будівництва та архітектури, Україна, Одеса; Приватне підприємство "Композит", Україна, Одеса

Пропонується створити у місті Одесі "Корпоративний науковотехнічний комплекс містобудівної енергореконструкції "КНТК МЕРек", 
як інноваційну організаційну структуру, яка використовує на практиці накопичений науково-технічний потенціал для реконструкції будівель історичної забудови Одеси за стандартами енергоефективності. Виконано дослідження історично-стильового розвитку Одеси в XIX $\ldots$ на початку XX століть, який характеризується великим розмахом будівельних робіт та наявністю різноманітних стилів (класицизм, бароко, романтизм, конструктивізм). Враховуючи, що розташування нового будинку в щільному ряду історичної забудови заборонено, то виходом з такої ситуації є надбудова будівлі новим об'ємом. Надбудови виконувалися в місті практично в ході всієї історії його розвитку. Ефективним варіантом надбудови будівель фонової забудови є мансардний поверх.

Ключові слова: корпоративний науково-технічний комплекс, містобудівна енергореконструкція, фрормування Одеси, архітектурні стилі, будівлі історичної забудови.

Introduction. Cities - generation a human society - total some millenia of the existence. Destinies cities are various and instructive: one have ceased to exist for a long time, others have grown till the huge sizes; one stay in oblivion, other steels world famous. The ancient history the majority cities clearly appears in character their lay-out and a silhouette. Each epoch and each society spontaneously or meaningly transformed and adapted those cities which received in the inheritance from previous epoch for the requirements.

The concept covers «the town-planning inheritance» both separate houses, and the big quarters, zones the historical centers and a city as a whole; which, today representing the big art value, is frequent in «a pure kind» is functionally a little suitable for use [1...4]. 
The review of last sources of researches and publications. Value of a historical architecturally-town-planning heritage is defined by following positions: architectural and town-planning achievements of last epoch are one of the major components of a historical and cultural heritage; history and culture monuments, the historical architecturally-spatial environment enriches shape of modern cities; presence of the developed ensembles causes aspiration to harmony with surrounding context.

According to varying social and economic conditions of a life in a city organism naturally die off old fabrics and are born new, therefore updating of cities occurs consistently, by replacement of an out-of-date supply available and gradual transformation by this basis planned structures in whole or its separate elements. The purpose of reconstruction and restoration of an architecturally-town-planning heritage is preservation of composite and aesthetic features of the historical city environment. Townplanning reconstruction is a purposeful activity on change before the generated town-planning structure, caused by requirements of development and perfection. The concept reconstruction of cities has double sense. On the first, it reflects development of the occupied places, improvement of their spatial organisation, proceeding long time. On the second, it is material result, a building condition at present. Only having understood these parties of reconstruction in their interrelation, it is possible to approach correctly to an estimation of problems and to establish methods of a reorganization of cities. Reconstruction - the continuous process which is passing in each city differently depending on the previous growth and modern requirements. It predetermines value of a city as historical phenomenon in which various epoch intertwine. And in a modern city organism its components continuously change [1...4].

Allocation unresolved before parts of the general problem. In townplanning is shown the tendency to integration, both in sphere of production 
of goods, and in management sphere; the expanded reproduction demands the further increase of level a division of labor, concentration and specialization of building manufacture, an intensification of an exchange of results is industrial-economic activities.

Problem statement in a general view. As one of perspective forms of integration various complexes act in town-planning structure; in the course of formation of plans of social and economic development of large cities even more often there is a situation when for increase of efficiency used financial, material and a manpower concentration of efforts, but also new progressive forms of the organisation of building manufacture - corporate, scientific and technical is necessary not simply, power efficiency.

Research objective. To offer the organizational structure using in practice the saved up scientific and technical potential for reconstruction of buildings of historical building of Odessa 1820...1920 years under standards power efficiency and execute research historically-style development of Odessa in XIX... in the beginning of the XX-th centuries.

The basic material and results of researches. As leading sign expediency application coordination principles of management the generality the economic purposes and the problems, demanding industrial cooperation acts.

From positions methodology management CSTC T-PPR is the economic object the new class which has received the name integration. Its specificity follows from its integrated approach.

Such are the most general features, testifying that at the organisation management CSTC T-PPR it is impossible to adapt only an operating economic mechanism, search of new forms and methods is necessary. In effect, the main problem is today maintenance coordination in activity of the controls concerning various links and levels building branch. Suggest them to unite "under the general roof" more often. But such structures are too 
bulky, unhandy, and are not always realized in practice, especially in building. It is necessary to organize thus participants CSTC T-PPR that they, realizing own purposes, would reach also the general results - we will tell, with partners in building of those or other building objects or with accessory manufacturers, though and not participating directly in works, but providing them, etc. Such mechanism is a coordination. Integrity CSTC TPPR is given by not so much spatial organisation, how many that end result - a product of manufacture of reconstruction which and is created by builders. Now, when the emphasis becomes on economic control levers, neglect lessons coordination management in relation to primary economic cells are necessary for considering.

At legislative level in Odessa operate: the Program of support of investment activity in territory of a city Odessa on 2016... 2018 [5] which acceptance is caused by necessity creation conditions for activization of the investment activity directed on improvement environment for conducting business and economic activities, improvement of the general macroeconomic indicators, as consequence maintenance of constant social and economic development of a city Odessa; and the Complex Program of development building in the city Odessa on 2013... 2018 [6] which is directed on the decision such basic problem questions town-planning sphere of a city Odessa as housing construction development, and also updating a technical condition of objects social appointment and an engineering-transport infrastructure.

Successfully to develop CSTC T-PPR it is necessary to consider changes in a control system of municipal economy, and the happened cardinal changes in economy. Especially it concerns problems with acceleration of technical updating of sphere of manufacture of building materials. 
Reconstruction of historical building has the big social and economic value. Its primary goals consist not only in prolongation of service life buildings, but also in liquidation physical and an obsolescence, improvement conditions residing, equipment of residential buildings by the modern engineering equipment, increase operational characteristics and architectural expressiveness. In Odessa in a context of the international integration to standards power efficiency buildings city target programs operate: the City target program of inclusion of the central historical part of building Odessa to the basic list of the World inheritance of UNESCO on 2013...2018 [7] and the City Program power efficiency of Odessa on 2013...2018 [8].

As a result of an unsatisfactory condition of an available housing, an street-road system, engineering communications, deterioration of comfort of residing, and as a whole losses of integrity perception the historical environment in the central historical area the city, and also deterioration of tourist and investment appeal the city complex target program «Preservation of authentic building and development of the historical centre of Odessa» [9] is developed.

Within the limits of these programs it is necessary to execute reconstruction of buildings historical building of Odessa $1820 \ldots 1920$ years under standards power efficiency.

For reception of these data in operational subsections CSTC T-PPR the scientifically-proved gathering the information on buildings of historical building city of Odessa should be adjusted.

Within the limits of this research it is defined:

Formation of Odessa on border XVIII and XIX centuries. The order on formation Odessa by empress Ekaterina has been signed 27.05.1794. The influence on the scheme the future city have imposed local climatic features, a lay land, receptions local architecture the people which occupied 
Northern Black Sea Coast (Ukrainians, Russians, Greeks, Moldovans, Tatars and others). Let about itself know remoteness Odessa from industrial and raw bases - at first to a city brought all: from nails and building wood to paints, wall-paper and furniture. On a birch of Black sea experts-foreigners started build a new city. The domestic qualified masters did not suffice. To the first masters belong: P. Dzhenari, A. Zheleznyakov, P. Ivashev, L. Kruthover, G. Pitstsamano and others.

Classicism epoch in Odessa - XIX ... first half of XX-th centuries. Opening in Odessa Porto Franco became a push for strengthening role of a city, as southern gate of Russian empire. Odessa which totaled in 181732 000 people of the population, to the middle of XIX century became a hundred-thousandth city. The Governor general of Novorossisk edge in 1823 became prince M. S. Vorontsov. Time of its board was marked by wide scope of building and gardening. Undivided rule in architecture stylistics was got by mature classicism. Up to the end 1820th years the city housing estate has sharply changed. On change to one-storied small houses send two-both three-storied imposing palaces and nobility private residences, profitable houses - the new type of habitation dictated genesis capitalist relations. Open galleries on all floors, turned into a court yard - a tribute to a southern climate city became an obligatory element both the first, and the second. The getting stronger class of the Odessa financial oligarchy and prosperous merchant class, under the influence of increasing communications with the countries of Europe and strengthening of architectural tendencies eclecticism, wished transferring these "new" forms to building practice of Odessa. In parallel with it, traditions mastery an epoch of classicism remained thanks to positive conservatism of Building Committee under control of G. S. Morozova. The city Building Committee organized still in February, 1804, was engaged not only realization a townplanning policy in a city, the control over work contractors and quality 
buildings. It also was border on a way of penetration local original architecture the deprived taste of influences. That diligence with which contributes to itself office-work of Building Committee, fixing each new building in Odessa was conducted. For convenience the control, according to the administrative division, all territory city shared on four areas - parts, each which was headed by the city architect appointed Building Committee. On a first line of an architectural life there are new masters - I. O. Dallakva, F. K. Boffo, I. S. Kozlov, N. N. Cherkunov.

Architecture of second half XIX century. After Petersburg and Moscow, Odessa has received privileges in self-management. Population growth, basically at the expense of immigration proceeds. A special role intensifications development city and port were played by input in 1865 of a railway branch Odessa-Balta. On it the raw materials for the enterprises, grain for export - the main goods which involved both domestic, and foreign merchants have smoothly begun to flow from "remote places". In a life of architectural Odessa in 1864 two events which have affected building stylistics have taken place - the Building Committee has been abolished and the Society of engineers and architects is created. The protest concerning the academic classicism was splashed out on facades buildings diverse and different style motives. As base for a composite variety new types successes archeology and architecture history served; the new building machinery and new building materials, designs from pig-iron, a steel and concrete. So, creativity the Odessa masters of second half XIX century, however, as well as all epoch, was original and inconsistent.

Ways architecture of the beginning the $X X$-th century. The European architecture $\mathrm{XIX} \mathrm{...} \mathrm{the} \mathrm{beginnings} \mathrm{of} \mathrm{the} \mathrm{XX}$-th centuries as the sponge absorbed all progressive achievements of science and technology. The assortment building materials has considerably extended - metal bearing elements, glass, reinforced-concrete became usual. There were first electric 
elevator and lifts. The newest building materials, wide-span constructive schemes buildings were not put any more in eclecticism borders. Diligence of masters the new architecture which tries to tear with the past architecture modernist style painfully was born. The term "modernist style" is defined as the phenomenon which is conscious and sharp against inheritance, the phenomenon time the big social shocks - thresholds of revolutions. To a decor the role "pure" and even the refined ornament though, it is not obligatory for a composition new style is taken away. Penetration new theories and building receptions into Odessa was accompanied by the further development industry of building materials manufacture brick of different marks, metal structures which supersede traditional limestone-shell rock and a tree has essentially increased, use of reinforced-concrete for erection the bases and hydraulic engineering constructions, materials for paving roads was adjusted. By the end of XIX century Odessa has firmly taken the third place in an economic life of empire, conceding only to Moscow and Petersburg. Large businessmen and industrialists became the basic customers in building.

Role background building in town-planning integrity the historical environment a city. In the city of Odessa is more than 1000 monuments of architecture. On modern concepts, is inadmissible consider unique and outstanding constructions out context of its environment from which, its perception appreciably depends. Its environment is one criteria «the test for authenticity» a monument (developed by the International Convention on protection the World cultural inheritance). For this reason for safety city context separate monuments architecture the great value has the fair approach to background building surrounding them and town-planning integrity. The historical city centre is presented mainly by buildings XIX ... the beginnings of the $X X$-th centuries the different town-planning importance. In such areas shortage platforms for new building and growth 
of cost the earth is felt. The arrangement new house in a dense number historical building is forbidden or does not give possibility for its further development. The superstructure buildings in new volume will be an exit from such situation. Superstructures were carried out in a city practically during all history its development. The mansard floor is an effective variant a superstructure buildings of background building.

Conclusions. It is offered to create in the city Odessa "the Corporate scientific and technical complex town-planning power reconstruction "CSTC T-PPR", as the innovative organizational structure using in practice the saved up scientific and technical potential for reconstruction buildings historical building of Odessa 1820...1920 years under standards power efficiency. In XIX ... the beginning of the XX-th centuries historically-style development city of Odessa is characterized by the big scope civil work and presence various styles (classicism, baroque, romanticism, constructivism).

\section{References:}

1. Posternak I. M., Posternak S. A. (2016). Corporate scientific and technical complex town-planning power reconstruction "CSTC T-PPR" Odessa. The development of international competitiveness: state, region, enterprise: materials of the International scientific conference. Lisbon, Portugal: Baltija publishing. Part II. Volume 1. Business economics and corporate management: innovation problem. pp. 6-8.

2. Posternak, I. M., \& Posternak, S. O. (2016). Korporativnij naukovotehnichnij kompleks mistobudivnoï energorekonstrukciï KNTK MERek: vitoki [Corporate scientific and technical complex town-planning power reconstruction CSTC T-PPR: sources]. In Scientific horizons - 2016 (Vol. 1, pp. 26-29). Sheffield: Science and education LTD (in Ukrainian).

3. Posternak, I. M., \& Posternak, S. A. (2016). Sohranenie ob'ektov kulturnogo naslediya Odessyi $s$ uchetom energomenedzhmenta 
[Preservation objects of a cultural heritage of Odessa with the account power management]. Preservation of historic buildings in the central part of Odessa via inscribing in the UNESCO world heritage list (pp. 220-223). Odessa: Astroprint (in Russian).

4. Posternak I. M., Posternak S. A. Die kalenderplanung bei der organisation des baues des komplexes städtebaulich energetischrekonstruktion. Economy and society: a modern foundation for human development: materials of the II International scientific conference, Germany, Leipzig, June 23th, 2017; Leipzig university: Faculty of economics and management science. Baltija publishing, 2017. Part II. P. 44-47.

5. Prohrama pidtrymky investytsiinoi diialnosti na terytorii mista Odesy na 2016-2018 [Programme support investment in the city of Odessa in 20162018] (Ukraine) 16 March 2016, No 438-VII. Retrieved from URL: http://omr.gov.ua/ru/acts/council/81386/ (in Ukrainian)

6. Kompleksna Prohrama rozvytku budivnytstva u misti Odesi na 20132018 [Integrated Development Programme building in Odessa in 20132018] (Ukraine) 17 December 2013, No 4196-VI. Retrieved from URL: http://omr.gov.ua/acts/council/56540/ (in Ukrainian)

7. Miska tsilova prohrama vkliuchennia tsentralnoi istorychnoi chastyny zabudovy Odesy do osnovnoho spysku Vsesvitnoi spadshchyny YUNESKO na 2013-2018 roky [City target program include central historical part of Odessa area to the main UNESCO World Heritage Site in 2013-2018 years] (Ukraine) 16 April 2013, No 3313-VI. Retrieved from URL: http://omr.gov.ua/acts/council/49938/ (in Ukrainian).

8. Miska tsilova prohrama enerhoefektyvnosti m. Odesy na 2013-2018 roky [City target program of energy efficiency. Odessa in 2013-2018 years] (Ukraine) 21 December 2012, No 2454-VI. Retrieved from URL: http://omr.gov.ua/acts/council/47098/ (in Ukrainian). 
9. Official Site of Odessa. (2017, November 1). Razrabotka koncepcii razvitija Central'nogo istoricheskogo areala Odessy [Development of the concept of the central historical area of Odessa]. Retrieved from URL: http://omr.gov.ua/ru/essential/89744/ (in Russian). 